\title{
European Refugee Crisis: Where Do Public Intellectuals Stand?
}

\author{
Pilar Damiao De Medeiros ${ }^{31}$ \\ University of Azores, Protugal
}

Doi: 10.19044/esj.2018.v14n5p410 URL:http://dx.doi.org/10.19044/esj.2018.v14n5p410

\begin{abstract}
The European refugee crisis has become one of the most puzzling aspects of European society and politics. The continent's worst humanitarian crisis since World War II has prompted a novel political and social labyrinth. As European leaders struggle to respond to the increasing number of refugees crossing their countries' borders, divisions tend to become more visible in the public debate. This paper explores the different positions of European public intellectuals: from French intellectuals, such as Finkielkraut, Houellebecq and Onfray, who tend to show sympathy with right-wing Islamophobic populism, to Jürgen Habermas, Zygmunt Bauman, Slavoj Zizek, among others, who appeal to relieve the refugee emergency. Whereas some still condemn war and imperialism, oppression and the violation of universal values, others appear to be embedded in national parochialism and dangerous radical positions.
\end{abstract}

Keywords: European refugee crisis, public intellectuals, public debate, Islamophobia, universal values.

War, political persecution, genocide, ethnic conflicts in various countries, especially in the Middle East (namely, in Syria, Iraq and Afghanistan) and North Africa, are victimizing millions of civilians and mass producing refugees. ${ }^{32}$ The "human tsunami" arriving in Europe is not only challenging European governments and European citizens but also defying European ethical and moral values. The shadow of the hours of horror from the past seems to be reemerging. In a lecture delivered in 2005, Edgar Morin

31 University of Azores, Interdisciplinary Centre of Social Sciences CICS.UAc/CICS.NOVA.UAc, UID/SOC/04647/2013, with the financial support of FCT/MEC through national funds and when applicable co-financed by FEDER under the PT2020 Partnership Agreement.

${ }^{32}$ It is important to establish a connection between migration and conflict, especially if conflict degenerates into civil war (Syria), the decomposition of a country (Iraq, Somalia, Afghanistan), the prosecution of religious communities (Nigeria) or the persistence of oneparty regimes with totalitarian tendencies (Eritrea). 
(2005: 92) stressed that we must be constantly regenerating our democratic conditions, so they don't degenerate, and must keep in mind the European evil and barbarity, so we won't repeat it:

Europeans have to be capable of conceiving European barbarity in order to transcend it, because the worst is still possible. Amid the threatening wasteland of barbarity, we are for the moment in a relatively protected oasis. But we also know that we are living in historical, political, and social conditions that make the worst conceivable, particularly in moments of paroxysm.

Presently, Europe is dealing with a twofold dilemma: on the one hand, the threat of terrorism is shaking Europe's safety and democratic values and, on the other hand, we are observing the escalation of Islamophobic discourses against those who are determinedly running away from the same terrorists and prosecutors, i.e. the refugees.

The corrosion of the basic principles of refugee protection, the exclusionary criteria, the prerogatives of territorial control, the rhetoric of farright activists and hate mongers in various Member-states - take the example of Geert Wilders in the Netherlands, Marine Le Pen in France, Viktor Orbán in Ungary, Nigel Farage in the UK, and now, the Neo-nazi party AFD [Alternativ für Deutschland] in the German Parliament - remind us of the darkest times and demons we had hoped had been exorcised long ago. Embedded in a discourse of fears: fear of immigrants, fear of refugees, fear of Islam, fear of terrorism, fear of economic uncertainty, they have succeeded in creating a social and cultural aversion to the "unheimlich Other". They portray refugees as religious fanatics, if not as terrorists, and as "fortune hunters" that want to live a luxurious, lazy life at the expense of "hard-working" European citizens. Even though the refugee crisis has originated mass mobilization of not just established civil society actors but also of Europeans of all nationalities and ages, it has, nevertheless, become clear that Western politicians are increasingly determined to restrict the influx of refugees. See for instance the EU-Turkey Agreement on Syrian Refugees (March $18^{\text {th }}$ ). According to Mehmet Ugur (2016),

the recent deal ... is a shameful example of European public policy captured by veto groups, which consist of minority xenophobic groups and politicians concerned about their chances of re-election. The deal consists of three elements: (i) for each Syrian refugee returned from Greek islands to Turkey the EU will accept one Syrian asylum seeker from Turkey; (ii) the agreement will not apply to other nationalities (e.g., nationals of Afghanistan, Pakistan or even Iraq); (iii) extra financial assistance of 
$€ 3$ billion to Turkey, which doubles the promised aid to $€ 6$ billion. The United Nation's High Commission for Refugees (UNHCR), Amnesty International and others have already indicated that the deal is morally flawed and may be illegal. Essentially, it boils down to enforced deportation because both Syrian and non-Syrian refugees to be returned to Turkey will be deprived of their right to be heard in courts. Secondly, the deal implies sending refugees to Turkey, a country considered unsafe by human rights organizations. The latter have long criticized Turkey for detaining refugees arbitrarily, sending them back to dangerous countries, and obstructing their access to the jobs market.

For Noam Chomsky (2016), with this Agreement, "Europe is trying to induce Turkey to keep the miserable wrecks away from their borders, just as the US is doing, pressuring Mexico to prevent those trying to escape the ruins of US crimes in Central America from reaching US borders. This is even described as a humanity policy which reduces 'illegal immigration." This controversial pack has generated multiple critical voices and seems to erase from memory the millions of desperate refugees who, during WW II, wandered on a fragile and contingent basis throughout Europe. For Mohamed Salih Ali, the coordinator of the NGO Association for Solidarity with Syrian Refugees, "Syrians have become a commodity traded and sold in the international bazaar but no one is thinking of solving the causes of the problem ... Everyone is thinking about how to throw the problem on the other." Along with this argument, we can venture to say that refugees have become "the ultimate test of morality in our ambivalent times" (Barmaki, 2009, p. 263).

At this point, it is important to recall the legal definition of refugee. According to Article 1(A)(2) of the 1951 Convention (UNHCR), ${ }^{33}$ a refugee is
[a]n individual who owing to well-founded fear of being persecuted for reasons of race, religion, nationality, membership of a particular group or political opinion, is outside the country of his nationality and is unable or,

\footnotetext{
${ }^{33}$ Bhambra (2015), "All EU countries are signatories to the 1951 Convention on refugees and the subsequent 1967 Protocol. This means that we are obligated, by law and not just by moral conscience, to comply with their substantive provisions and to offer refuge and protection to people fleeing political or other forms of persecution. ... While refugees have rights under international law, people who come for other reasons are labeled as migrants and deemed not to have any claims upon the states to which they are seeking entry. ... The economic motivation that drives poorer people to migrate has been produced and continues to be reproduced by practices emanating from richer countries and their own deficient understandings of their global dominance."
} 
owing to such fear, unwilling to avail himself of the protection of that country; or who, not having nationality and being outside the country of his former habitual residence as a result of such events, is unable or, owing to such fear, is unwilling to return to it.

The contemporary dystopia involving the lives of refugees, Syrians in particular, is being fueled by multiple factors; while they flee from Assad and ISIS, from the violence and destruction perpetrated by both, they find themselves trapped in a state of "liminal drift" on European soil. Indeed,

Syrians have been fleeing in historical numbers and seeking refugee in neighboring countries. Turkey, with an existing population of 74 million, has taken in close to two million refugees from Syria; Lebanon has taken in over a million, despite only having a population of 4.5 million. Europe, on the other hand, has been largely bickering over how many refugees to take, whether they are genuinely escaping conditions of war, or speculating on how these 'floods' or 'swarms' of 'migrants' would irreducibly alter the face of Europe. With a couple of notable exceptions - Sweden, primarily, and more recently, Germany - European Union member countries seem to have been more interested in scaremongering than honoring their treaty obligations to refugees under international law (Bhambra, 2015).

After the shocking image of the body of a three-year old Syrian boy, Alan Kurdi, European citizens and some politicians revealed an incredible welcoming gesture ${ }^{34}$ towards the refugees. Nonetheless, following the Paris attack on November $13^{\text {th }}$, the Cologne New Year's gang assaults and Brussels attacks, such solidarity and empathy is gradually being replaced by fear and anger.

In spite of these horrific happenings, Europe must not follow the distorted worldviews founded on cultural biases and prejudgments and disregard the lives of the ones that "are subject to increasing harassment, hatred, detention, discrimination, criminalization, and transfer to remote and dangerous places" (Barmaki, 2009: 251). Once outside the borders of their native country,

the refugees are in a legal no-man's land and deprived of the backing of a recognized state authority that can take them under its protection, uphold their rights and

\footnotetext{
${ }^{34}$ On September 9, 2015, Jean-Claude Juncker gave a strong humanistic talk reminding us that Europe is itself a construction of emigrants and immigrants.
} 
intervene on their behalf with other powers. ... Out of their camps, they are out of place, viewed as obstacles and trouble; inside their camps, they are forgotten. All they have are walls, the barbed wire, the controlled gates, the armed guards; all measures to insure the permanence of their exclusion. They have no sense of individuality or identity, and no right to selfdetermination (Barmaki, 2009: 261).

Moreover, it is obscene and unthinkable that in contemporary Europe we are re-experiencing the most abominable and inhumanely conditions in such camps. Greece's interior minister, Panagiotis Kouroublis, even compared conditions at a crowded refugee tent city, the Idomeni camp, on the country's border with the Former Yugoslav Republic of Macedonia (FYROM) to a Nazi concentration camp, blaming the suffering on some European countries' closed border policies, "I do not hesitate to say that this is a modern-day Dachau, a result of the logic of closed borders" (18.03.16). These stateless people, on the brink of a humanitarian catastrophe, seem to have lost "a place on earth, they are catapulted into a nowhere" (Bauman, 2002: 122). In fact, they "are always in a psychological limbo because they are on a journey without an end since its destination remains unclear. Any stay is provisional, any settlement temporary" (Barmaki, 2009: 261). These masses of people, now trapped in a real life drama and beheld with reluctance and rejection by many European countries, are eager for only one thing: safety. In addition to these awful circumstances, we cannot also forget the tragic numbers of people that die in their journey to freedom: between 2000 and 2015 there were more than 22,000 victims in the Mediterranean (Rogeiro, 2015: 48).

The gigantic scale of this humanitarian crisis has led to a wide political and public debate about whether Europe should open its arms to these "unknown others" and, if so, in what terms, or whether it should close its frontiers and struggle against, according to some, the Islamization of Europe. At this point, it is interesting for us to observe where European public intellectuals stand on this debate. We can even illustrate how different discourses flourish in specific countries. Take for example Pierre Briançon's article "J'accuse: Leftist intellectuals turn right: Unusual ideological bedfellows in France are uniting against globalization and the euro" published in the European edition of Politico, in which he surprisingly remarks how French leftist public intellectuals are now presenting ideas similar to those of the far-right on immigration, while emphasizing the need to restore France's battered sense of self. According to Briançon (2015), along with Onfray's quasi-Islamophobic position, we can add other names, namely:

the moralist philosopher Alain Finkielkraut, a former left-wing radical and now member of the French 
Academy who has written several books on the waning of France's traditional republican culture and the country's 'unhappy identity' (the title of one of his books) ${ }^{35}$; Régis Debray, a 1960s companion of Che Guevara who later became an adviser to former Socialist president François Meditterrand; Eric Zemmour, a farright journalist and TV debater whose book 'Le suicide français' on 'the 40 years that destroyed France' became an unlikely best-seller last year; and even Michel Houellebecq, the recluse novelist whose latest book, 'Submission,' describes a future France as an Islamic theocracy.

For Laurent Joffrin, the editor of Libération, who led the anti-Onfray charge, "Europe is seen by those intellectuals as just the Trojan horse of globalization. What unites those intellectuals is opposition in general to modern times - to the governing left, to market-friendly Europe, to immigrants seen as the armies of Islam. But they never venture to tell us what should be done" (Briançon, 2015).

In sharp contrast with these positions, which portray a strong antiimmigration rhetoric and remind us of the intellectuals who, not so long ago in European history, also followed far-right, shallow, facile and populist concepts, we have others who still pursue an humanistic acknowledgement of rationality and a critical dethroning of conventional forms of rationality. In line with well-known humanist Edward Said (1996: xi), "the intellectual should offer alternatives to the 'staples of dominant discourse' ... the effort to break down the stereotypes and reductive categories that are so limiting to human thought and communication." In other words, intellectuals should challenge common sense generalizations and radical anti-foundationalism on behalf of human dignity. Furthermore,

[t] he intellectual's representations, what he or she represents and how those ideas are represented to an audience, are always tied to and ought to remain an organic part of an ongoing experience in society: of the poor, the disadvantaged, the voiceless, the unrepresented, the powerless. These are equally concrete and ongoing; they cannot survive being transfigured and then frozen into creeds, religious declarations, professional methods (Said, 1994: 113).

\footnotetext{
35 This philosopher recently defended the right of Nadine Morano, a French MP from Nicolas Sarkozy's party Les Républicains, to say that France was a "white race" country.
} 
Moreover, the intellectual "belongs on the same side with the weak and unrepresented. Robin Hood, some are likely to say," acknowledges Said (1994: 22). It is precisely this ability to raise moral questions about the nature of politics that led a group of 95 intellectuals, politicians and artists from central Europe ${ }^{36}$ (Zygmunt Bauman, Gordon Bajnai, Bronislaw Komorowski, Agnes Heller, among many others) to sign an open letter titled "An appeal from Central Europe on the refugee crisis" (18.09.2015):

This time has a moral dimension. It is true we are not accountable for the instability and collapse of refugees' home countries. We are not the ones who have turned them into states plagued by incessant fear, where people are at risk of violent death, and where human life is 'solitary, poor, brutish, and short.' ... Nonetheless, as human beings, we have the duty to show compassion and to provide them with assistance. This is also our duty as Europeans. The European community was founded on the principle of solidarity. Today we must not refuse to take joint responsibility for the Union, nor turn a blind eye to human suffering and the situation of countries most affected by the rising tide of migration. ... In the name of our humanity, our principles and values, we call upon the authorities and people of our region to demonstrate practical solidarity towards refugees so that they may find safe haven in our midst and enjoy freedom to choose their own future.

Interestingly enough, it was another open letter from Germany - a halfpage document signed by more than 70 prominent figures from the arts, culture, politics and civil society and published in the German newspaper Die Welt - that supported Merkel's refugee policy. "You have transformed our country. People no longer fear Germany; on the contrary: they want to come to Germany. After the horror and crimes that came out of Germany, this is a new, wonderful experience for us", the signatories wrote. Nobel laureate in literature Herta Mueller, conductor and pianist Daniel Barenboim, Holocaust survivor Margot Friedlander and producer Nico Hofmann are some of the names that have signed this letter. J. Habermas was also one of the public intellectuals who strongly supported Angela Merkel's asylum policy. In an interview last September for Deutsche Welle (29.09.2015), he claimed, "the right to asylum is a human right and everyone who applies for political asylum

36 This open letter was sent to EurActiv by the Stefan Batory Foundation (http://www.batory.org.pl), a private independent Polish foundation established in 1988 by American philantrophist George Soros and a group of Polish democratic opposition leaders of the 1980s. 
should be treated fairly." For many years, he emphasized, "I haven't been as satisfied with the government in Germany as I have been since the end of September." Regarding the military interventions in Iraq, Afghanistan, but also in Mali and Libya, western policy drew harsh criticism from him: "the intervention powers are not ready to make a long-term commitment, that is, decades of building up state structures in these countries. As a result, we see that the situation in the effected countries usually gets worse than better".

It is clear that, despite their divergent positions, European public intellectuals are being vital pieces in this highly demanding public debate.

In the meantime, in an article titled "How to justify a crisis," Nick Reimer (2015) questions the role and responsibility of intellectuals regarding the refugee crisis. He even selects articles by Slavoj Zizek, Juergen Habermas and Peter Singer and criticizes them for not being able to think outside the already established discourses on the crisis - "At no stage does the analysis go beyond what is already uncontroversial for large sections of the Western public" (Riemer, 2015) - and for upholding the strongholds of power:

As Zizek, Singer and Habermas's interventions demonstrate, intellectual authority can easily barricade the real strongholds of power and mystify its operations. For anyone who wants to put analysis to the service of fundamental social change, diagnosing and preventing this transformation of critique into intellectualism should be among the many responsibilities of 'intellectuals' today.

Although Habermas and Singer's public intervention is more moderate, Slavoj Zizek offers a discourse twisted by Eurocentric premises. For him, refugees

assert their dreams as their unconditional right, and demand from the European authorities not only proper food and medical care but also transportation to the destination of their choice. There is something enigmatically utopian in this demand: as if it were the duty of Europe to realize their dreams ... It is precisely when people find themselves in poverty, distress and danger - when we'd expect them to settle for a minimum of safety and wellbeing - that their utopianism becomes most intransigent. ... [I]t should also be made clear to them that they must accept the destination allocated to them by the European authorities, and that they will have to respect the laws and social norms of European states (Zizek, 2015). 
This argument pertains to the domain of rationality and instrumentality. Here the refugees' voice, wishes, desires and differences are relegated to an inferior, almost subordinate, position. Zizek (2015) also strongly criticizes both the rhetoric of left-liberals and anti-immigration populists. Public opinion, he argues, "is sharply divided. Left liberals express their outrage that Europe is allowing thousands to drown in the Mediterranean: Europe, they say, should show solidarity and open its doors. Anti-immigration populists say we need to protect our way of life: foreigners should solve their own problems. Both solutions sound bad". While disagreeing with both visions, he places himself between the two. Similarly to Habermas, he also identifies the West as responsible for the inoperative conditions of several states:

If we really want to stem the flow of refugees, then, it is crucial to recognize that most of them come from 'failed states,' where public authority is more or less inoperative: Syria, Iraq, Somalia, and so on. This disintegration of state power is not a local phenomenon but a result of international politics and the global economic system, in some cases - Libya and Iraq - a direct outcome of Western intervention (Zizek, 2015).

In a nutshell, it is crucial to question whether the critical mode of thinking, the philosophical, social and political positions, especially from the aforementioned French intellectuals, fit into the humanistic definition of "public intellectual." 37 For Said (2003b), "humanism is the only and ... the final resistance we have against the inhuman practices and injustices that disfigure human history". Furthermore, shouldn't a public intellectual break down stereotypes, instead of reinforcing them? Shouldn't an intellectual, in line with Z. Bauman, "mediate the communication between 'finite provinces' of 'communities of meaning" 38 and refuse the universality of truth? How

${ }^{37}$ E. Said (2003b), "By humanism I mean first of all attempting to dissolve Blake's 'mindforged manacles' so as to be able to use one's mind historically and rationally for the purposes of reflective understanding. Moreover humanism is sustained by a sense of community with other interpreters and other societies and periods: strictly speaking therefore, there is no such thing as an isolated humanist."

${ }^{38}$ Compare with Z. Bauman (1987: 197), "the strategy of interpretation does differ form all strategies of legislation in one fundamental way: it does abandon overtly, or put aside as irrelevant to the task at hand, the assumption of the universality of truth, judgment or taste; it refuses to differentiate between communities which produce meanings; it accepts those communities' ownership rights, and the ownership rights as the only formation the communally grounded meanings may need. What remains for the intellectuals to do, is to interpret such meanings for the benefit of those who are not of the community which stands behind the meanings; to mediate the communication between 'finite provinces' or 'communities of meaning.", 
should the radical and culturally/religiously biased political interventions of French public intellectuals be read? Insofar, does this debate really illustrate the decline (R. Jacoby, 1987) as well as the betrayal of public intellectuals towards progressive and humanistic moral values? Is this group of French intellectuals manifestly despising the suffering, repression and collective cruelty that refugees are experiencing? In fact, we can conclude that the European communities of resistance are presenting different forms of engagement when it comes to the debate on the European solution: some maintain their genuine commitment to the ideals of human freedom and dignity, while others, regrettably, exhibit a highly prejudiced and aggressive discourse that instigates fear towards the "Other."

We have to admit that Europe is currently dealing with a tremendously complex quandary. The European project is torn apart as many European countries, especially in the south, continue to suffer with severe austerity measures and increasing poverty. Along with the economic and financial crisis, Europe has to deal simultaneously with a new wave of independence movements (e.g. Brexit), as well as with the incoming of thousands of refugees and migrants. The road is hard, but the solution for a stronger and revitalized Europe must echo the raison d'être of European values, i.e., solidarity, freedom and respect for human rights. Furthermore, and since "one of the roles of the intellectual at this point is to provide a counterpoint, by storytelling, by reminders of the graphic nature of suffering, and by reminding everyone that we're talking about people. We're not talking about abstraction" 39 (E. Said, 2003a: 187), the European public intellectuals with non-biased beliefs should be engaged in this battle for social justice and human dignity.

\section{References:}

1. BARMAKI, R. (2009) "Criminals/Refugees in the Age of Welfare States: Zygmunt Bauman on Ethnicity, Asylum and the new "Criminal". International Journal of Criminology and Sociological Theory 2(1): 251-266.

2. BAUMAN, Z. (2002) Society under Siege. UK: Polity Press.

3. BAUMAN, Z. (2007) Liquid Times: Living in an Age of Uncertainty. Malden: Polity Press.

\footnotetext{
${ }^{39}$ Said (1994, p. 11), "The central fact for me is, I think, that the intellectual is an individual endowed with a faculty for representing, embodying, articulating a message, a view, an attitude, philosophy or opinion to, as well as for, a public." Said (1994, p. 98), "there is a special duty to address the constituted and authorized powers of one's own society, which are accountable to its citizenry, particularly when those powers are exercised in a manifestly disproportionate and immoral war, or in a deliberate program of discrimination, repression, and collective cruelty."
} 
4. BHAMBRA, G. K. (2015) "The Refugee Crisis and Our Connected Histories of Colonialism and Empire". Sicherheitspolitik-blog (Available at 01.10.2015).

5. BRIANÇON, P. (2015) "J'accuse: Leftist intellectuals turn right". Politico (Available at 16.10.2015)

6. CHOMSKY, N. (2016) "Noam Chomsky on Europe's Refugee Crisis and the Endless Greek Debt Drama". Interview conducted by C.J. Polychroniou. Greekreporter (Available at 27.01.2016).

7. FULLER, S. (2006) "The Public Intellectual as Agent of Justice: In Search of a Regime”. Philosophy and Rhetoric 39(2): 148-157.

8. JACOBY, R. (1987) The Last Intellectuals: American Culture in the Age of Academe. NY: Basic Books.

9. KOUROUBLIS, P. (2016) "Greek refugee camp is as bad as a Nazi concentration camp", The independent (Available at 18.03.16).

10. HABERMAS, J. (2015) "Asylum is a human right". Deutsche Welle (Available at 29.09.2015).

11. MORIN, E. (2005) Culture et barbarie européenne. Paris: Bayard.

12. Open letter "An appeal from Central Europe on the refugee crisis" (Available at http://www.batory.org.pl).

13. RIEMER, N. (2015) "How to Justify a Crisis?”. Jacobin (Available at 10.05 .15 )

14. ROGEIRO, N. (2015) Menos que Humanos: Imigração Clandestina e Tráfico de Pessoas na Europa. Alfragide: D. Quixote.

15. SAID, E. (1994) Representations of the Intellectual: The 1993 Reith Lectures. New York: Vintage Books.

16. SAID, E. (2003a) Culture and Resistance: Conversations with Edward Said. London: Pluto Press.

17. SAID, E. (2003b) "A window on the world". The Guardian (Available at 02.09.2013).

18. SAID, E. (2004) Power, Politics and Culture: Interviews with Edward W. Said. London: Bloomsbury.

19. UGUR, M. (2016) 'Eu-Turkey 'Agreement' On Syrian Refugees: An Illegal And Shameful Deal”. Social Europe (Available at 17.03.16).

20. ZIZEK, S. (2015) "The Non-Existence of Norway". London Review of Books online. (Available at 09.09.15). 